
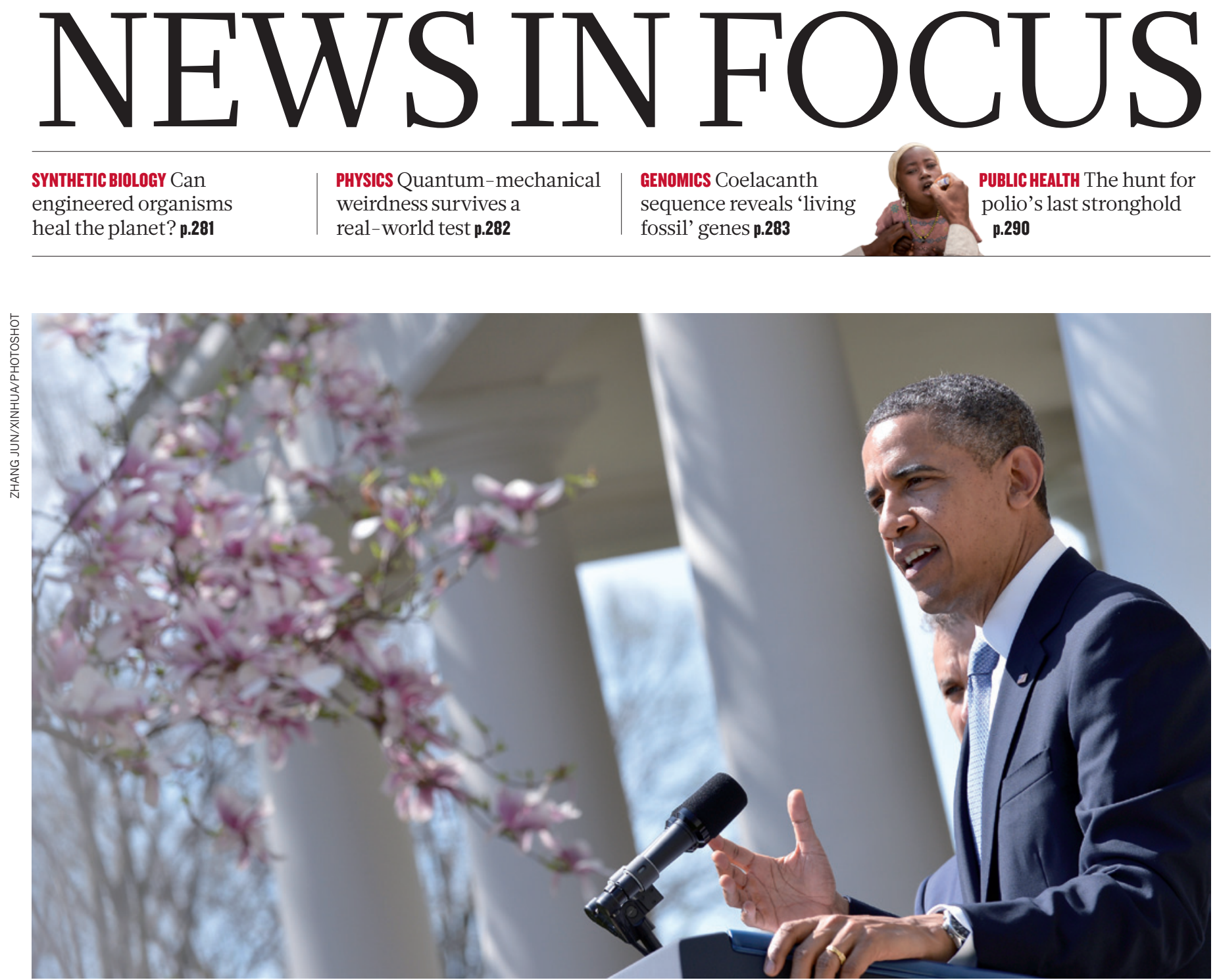

US President Barack Obama on 10 April unveiled a budget that proposes large increases for advanced manufacturing programmes.

\title{
A back seat for basic science
}

\section{Translational research wins in Obama's budget, but its economic value remains uncertain.}

\section{BY ERIC HAND, BETH MOLE, LAUREN MORELLO, JEFF TOLLEFSON, MEREDITH WADMAN AND ALEXANDRA WITZE}

The magnolia trees behind the White House were decked in blossoms as US

President Barack Obama announced his 2014 budget proposal on 10 April. They emphasized the lateness of the proposal, which is usually unveiled in early February. The short-lived flowers could also have symbolized a fragile optimism about the US economy. But with unemployment at a worrisome $7.6 \%$ and Congress insistent on deficit reduction, Obama's budget is cautious. The US\$3.8-trillion proposal would undo the across-the-board cuts known as sequestration, but includes just $\$ 143$ billion for research and development, a mere 1\% rise from 2012.

The budget reflects not only caution, but also the Obama administration's emerging attitude towards research: that science needs to be good for something, namely jobs and cures.

"To make America a magnet for good jobs, this budget invests in new manufacturing hubs," said Obama. "We'll spark new American innovation and industry with cutting-edge research like the initiative I announced to map the human brain and cure disease."

The first reference was to a one-time, \$1-billion request from the National Institute of Standards and Technology in Gaithersburg,
Maryland. The money would set up 15 manufacturing hubs, modelled after a pilot project devoted to three-dimensional printing that was established in 2012 in the former steelmanufacturing town of Youngstown, Ohio.

The second was to a multibillion-dollar brain-mapping project that would, in its first year, receive a total of $\$ 110$ million from the National Institutes of Health (NIH) in Bethesda, Maryland; the National Science Foundation (NSF) in Arlington, Virginia; and the Defense Advanced Research Projects Agency in Arlington. The project's first steps - creating tools to record the activity of millions of neurons - fall under basic research, but the White House has promoted the 
- project as key to understanding, treating and even curing brain diseases.

Those initiatives embody a spirit that runs throughout the proposal, reserving big boosts for research areas that promise nearterm economic and social benefits (see 'Tight times'). Adam Jaffe, an economist at Brandeis University in Waltham, Massachusetts, who specializes in science policy, says that the administration's emphasis is natural: it makes funding science more politically palatable in a difficult economic climate. "They want to make clearer arguments as to why this is helping people in the relatively short run, rather than helping pointy-headed scientists," he says.

But researchers unaccustomed to thinking about applications are starting to complain, says Jaffe. "They think it's outrageous that the NIH should ask them to talk about the actual health-care implications of their research."

Shifting money towards applications can leave basic research in the cold because the private sector will not support it, notes Barry Toiv, a spokesman for the Association of American Universities in Washington DC. Commercializing research discoveries can be a good idea, he says, but only if "the fundamental federal responsibility of funding basic research isn't undermined".

\section{PHYSICAL SCIENCES}

Under the budget proposal, NSF funding would rise by $8.4 \%$ over 2012 levels (used as a baseline because Congress did not finalize 2013 funding until late March). Much of that increase would go to purpose-driven initiatives such as the Cyber-Enabled Materials, Manufacturing and Smart Systems project, which would see its budget more than double, to $\$ 300$ million. The project funds research into new materials and robotics that could aid manufacturing.

The Innovation Corps (I-Corps), a training programme established in 2011 to guide researchers in turning their discoveries into products, was a pet project of former NSF director Subra Suresh, who stepped down last month. The programme's budget would more than triple to $\$ 25$ million under Obama's proposal. "I think this fulfils a need for the country," says Dean Chang, associate vicepresident of innovation and entrepreneurship at the University of Maryland in College Park, who was part of a team that won $\$ 3.75$ million from I-Corps this year to start a regional training centre. A dash of entrepreneurialism could allow "academia to contribute to the economic development of the country", adds James Chung, executive director of the Office of Entrepreneurship at the George Washington University in Washington DC.

Engineering, with its applied focus, would get the largest boost of any research division at the NSF: $10.3 \%$. That continues a trend: since the first Obama budget, for 2010, engineering funding has risen by $17 \%$, to $\$ 911$ million. Yet

TIGHT TIMES

In US President Barack Obama's budget request for 2014, applied research accounts for most of the increases in science funding (US\$ billions).

\begin{tabular}{|c|c|c|c|c|}
\hline Agency & $\begin{array}{l}2012 \\
\text { actual }\end{array}$ & $\begin{array}{l}2013^{*} \\
\text { estimated }\end{array}$ & $\begin{array}{l}2014 \\
\text { requested }\end{array}$ & Details \\
\hline \multicolumn{5}{|c|}{ Biomedical research and public health } \\
\hline National Institutes of Health & 30.70 & 30.90 & 31.17 & $\begin{array}{l}\text { Nearly flat, but translational-science } \\
\text { centre gets a } 16 \% \text { boost from } 2012\end{array}$ \\
\hline $\begin{array}{l}\text { Centers for Disease Control } \\
\text { and Prevention }\end{array}$ & 5.66 & 5.69 & 5.22 & $\begin{array}{l}\text { Includes } \$ 10 \text { million for research on the } \\
\text { causes and prevention of gun violence }\end{array}$ \\
\hline $\begin{array}{l}\text { Food and Drug } \\
\text { Administration }\end{array}$ & 2.51 & 2.52 & 2.56 & $\begin{array}{l}\text { Overall } \$ 4.7 \text {-billion budget includes } \\
\text { more than } \$ 2 \text { billion in user fees }\end{array}$ \\
\hline \multicolumn{5}{|l|}{ Physical sciences } \\
\hline $\begin{array}{l}\text { National Science } \\
\text { Foundation }\end{array}$ & 7.11 & 7.08 & 7.63 & $\begin{array}{l}\text { An } 8 \% \text { rise, with a robotic- } \\
\text { manufacturing programme seeing a } \\
\text { large gain }\end{array}$ \\
\hline NASA (science) & 5.07 & 5.12 & 5.02 & $\begin{array}{l}\text { Mission to capture an asteroid debuts, } \\
\text { and funding to monitor near-Earth } \\
\text { objects would double }\end{array}$ \\
\hline $\begin{array}{l}\text { Department of Energy } \\
\text { Office of Science }\end{array}$ & 4.93 & 4.90 & 5.15 & $\begin{array}{l}\text { Increases funds for applied and } \\
\text { interdisciplinary energy research }\end{array}$ \\
\hline $\begin{array}{l}\text { National Institute of } \\
\text { Standards and Technology }\end{array}$ & 0.75 & 0.76 & 0.93 & $\begin{array}{l}\text { Agency is also pursuing a one-off } \\
\text { request for } \$ 1 \text { billion to fund up to } \\
15 \text { manufacturing-innovation institutes }\end{array}$ \\
\hline \multicolumn{5}{|l|}{ Earth and environment } \\
\hline $\begin{array}{l}\text { Environmental Protection } \\
\text { Agency }\end{array}$ & 8.45 & 8.50 & 8.15 & $\begin{array}{l}\text { A } 3.5 \% \text { decline from } 2012 \text { includes } \\
\text { hits to research, as agency prioritizes } \\
\text { cutting greenhouse-gas emissions }\end{array}$ \\
\hline $\begin{array}{l}\text { National Oceanic and } \\
\text { Atmospheric Administration }\end{array}$ & 4.91 & 5.26 & 5.45 & $\begin{array}{l}\text { A plan to maintain continuity in } \\
\text { weather-satellite data would shift } \\
\text { climate sensors to NASA }\end{array}$ \\
\hline US Geological Survey & 1.07 & 1.08 & 1.17 & $\begin{array}{l}\text { Boosts spending on ecosystem } \\
\text { research and climate science }\end{array}$ \\
\hline
\end{tabular}

*2013 figures do not include the roughly $5 \%$ across-the-board cut arising from the sequester.

Source: White House Office of Management and Budget

the maths and physical-sciences division has barely gained at all, increasing from $\$ 1.37$ billion in 2010 to $\$ 1.39$ billion for 2014 (see 'Apply thyself').

\section{BIOMEDICINE AND PUBLIC HEALTH}

The NIH, ever popular with the public and with patients' groups, often gets more from Congress than the president requests. For now, the administration is calling for a boost of just $1.5 \%$ over 2012 levels, to $\$ 31.2$ billion.

Projects that aim to speed treatments from labs to patients did much better. The fledgling National Center for Advancing Translational Sciences received a $16 \%$ boost to $\$ 666$ million - by far the biggest jump, proportionately, among the agency's 27 institutes and centres. A big chunk of that - $\$ 40$ million - is an increase for the Cures Acceleration Network, which aims to make awards of up to $\$ 15$ million for work on 'high need' cures that industry is unlikely to develop.

The White House also returned to a problem that it first flagged up for special attention last year: Alzheimer's disease, which cost the nation as much as $\$ 215$ billion in 2010 , according to a study published on 4 April (M. D. Hurd et al. N. Engl. J. Med. 368, 1326$1334 ; 2013)$. The budget would add $\$ 80$ million to the roughly $\$ 500$ million that the $\mathrm{NIH}$ is already spending on the disease.

"The NIH has always had this dual configuration as a science agency and as a health agency," says Irwin Feller, a science economist at Pennsylvania State University in University Park, adding that the second function has expanded in recent years. The proportion of $\mathrm{NIH}$ money spent on basic research has fallen from two-thirds in the 1980s and 1990s to just over half now, says Matt Hourihan, director of research and development budget and policy at the American Association for the Advancement of Science in Washington DC.

Supporters of basic research "don't particularly like" that trend, says Ben Corb, director of public affairs at the American Society for Biochemistry and Molecular Biology in Rockville, Maryland. He says that the NIH is feeling pressure from members of Congress, who "are asking: what are we getting for the $\$ 30$ billion we're giving the NIH? Where are our cures? Where are our treatments?"

\section{ENERGY}

The Department of Energy (DOE) has always embodied the tension between basic and applied research. Its mission is to support applied work on energy extraction, even as its Office of Science funds blue-sky research that may not have applications for decades. 
The White House request would boost the DOE's budget to $\$ 28.4$ billion, nearly $8 \%$ above 2012 levels, with the largest increase - almost $\$ 1$ billion - for initiatives targeting energy efficiency, renewables and advanced manufacturing. Clean energy "has been the signature of this administration", says Michael Lubell, director of public affairs for the American Physical Society in Washington DC.

Investment would continue to flow to translational science at the Energy Innovation Hubs and Energy Frontier Research Centers initiated by departing energy secretary Steven Chu. The administration is also asking for a $38 \%$ rise in funding for high-risk work at the Advanced Research Projects Agency-Energy (ARPAE), which was designed to bridge a 'valley of death' between basic and applied energy research. Support for the hubs and ARPA-E has faced resistance from Republicans in Congress, wary of picking winners in the applied sector. But Obama's administration hopes to launch prize schemes that, by providing incentives for innovation, may draw more bipartisan support. The budget includes $\$ 200$ million in a one-time 'race to the top' for states that provide the best proposals for investing in energy efficiency and advanced electricity-grid technologies, and a $\$ 25$-million prize for the first natural-gas combined-cycle plant to be equipped with carbon capture and sequestration technologies.

One of the largest increases in the Office of Science was reserved for basic energy sciences, a programme that, despite its name, supports applied 'use-inspired' materials research. Its budget would grow by $10 \%$ from 2012 . Meanwhile, high-energy physics would suffer a $1.8 \%$ loss. With the shutdown of the Tevatron at Fermi National Accelerator Laboratory in Batavia, Illinois, in September 2011, the locus of activity in the field has shifted to the Large Hadron Collider at CERN, Europe's highenergy physics laboratory near Geneva, Switzerland. The budget cut will force officials at the DOE to make tough choices about remaining physics experiments, such as neutrino studies.

\section{SPACE AND EARTH SCIENCES}

NASA has been mission-oriented ever since it was tasked in 1961 with going to the Moon. Although some officials still advocate a return to the Moon (see Nature 492, 161-162; 2012), this year, the president's budget proposal arrived on the same day as a congressional

\section{APPLY THYSELF}

Emphasizing applications, engineering has seen large gains at the US National Science Foundation.

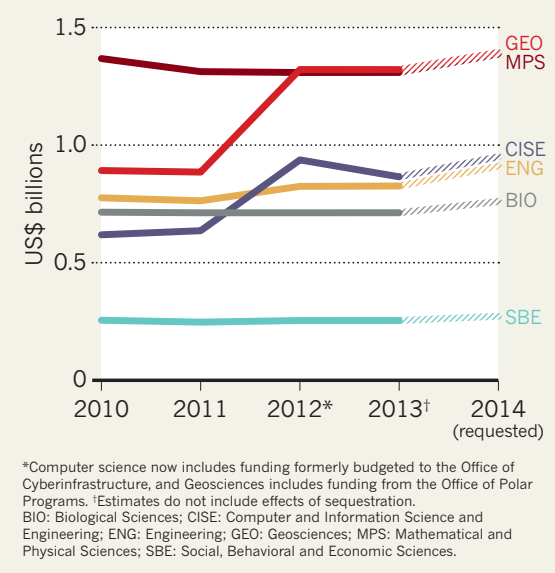

hearing on the dangers of near-Earth asteroids, which seem to be the agency's current focus.

NASA wants to double the $\$ 20$ million spent annually on hunting dangerous space rocks, mainly to track smaller ones and to identify a candidate for a surprising mission. If Congress approves the administration's proposal, NASA would perform the first-ever asteroid-capture mission, in which a robotic spacecraft would snatch an asteroid 7-10 metres across, and tow it back to the vicinity of the Moon. Astronauts aboard the Orion crew vehicle could then visit and study the rock as early as 2021 . The agency is asking for $\$ 38$ million to develop solar electric propulsion for the robotic part of the mission, and $\$ 40$ million to study how astronauts would work with the 'uncooperative target'.

The Obama administration has emphasized NASA's Earth science, which would receive a 5\% increase from 2012 levels. Other Earthobserving programmes, run by the National Oceanic and Atmospheric Administration (NOAA), also benefit in the request. Funding for NOAA's satellite division, which operates geostationary weather probes and the Jason-3 altimetry mission to monitor sea-level rise, would increase by $17 \%$, to $\$ 2.2$ billion, outpacing the $11 \%$ increase for the agency overall.

Astrophysics and planetary science at NASA would suffer cuts of $1 \%$ and $19 \%$, respectively, from 2012 levels. Yet those two divisions would still get big prizes: the James Webb Space Telescope, an infrared successor to the Hubble
Space Telescope that is on track for a 2018 launch, and a Mars rover to launch in 2020, built of spare parts from the Curiosity rover.

\section{REALITY CHECK}

As with all presidential budget requests, Obama's priorities are contingent on Congress. Mark Muro, a senior fellow at the Brookings Institution, a think tank in Washington DC, says that many of Obama's budget initiatives may amount to little more than "performance art" given the political focus on the deficit.

If the emphasis on commercially tinged basic research is to continue, science and technology economists agree that its value needs to be measured carefully. "It's a little hard to know how well it works, because we don't do any serious evaluation of these programmes," says Jaffe.

That means measuring not just monetary returns on investments, but also the social return, says Julia Lane, an economist at the American Institutes for Research in Washington DC who until last year headed NSF efforts to measure research outputs. Negative results are part of the picture, she says. Private oil prospectors might not disclose locations that hold no oil, whereas the US Geological Survey would, which would benefit society. Similarly, unlike the NIH, drug companies may not report negative clinical-trial results.

When mission-driven research is done at universities rather than in industry, it has an indirect social benefit: students who go on to found spin-off companies, says Lane. "The best way to translate knowledge is to wrap it up in a human being," she says. "We need to capture that piece of information."

Translational research can have pay-offs for basic science, says Matthew Begley, a mechanical engineer at the University of California, Santa Barbara, who, along with his colleagues, received $\$ 1.2$ million from the NSF to study high-temperature materials that could be used in aeroplane engines. He points out that the best scientists hop back and forth between basic and applied endeavours, and that basic research draws on applied science just as often as the other way around - witness the Large Hadron Collider, whose construction required major feats of engineering to allow it to discover the Higgs boson. "The line between science and technology is sort of blurry," says Begley. "But when they're done well, the line is very blurry." - SEE EDITORIAL P.269

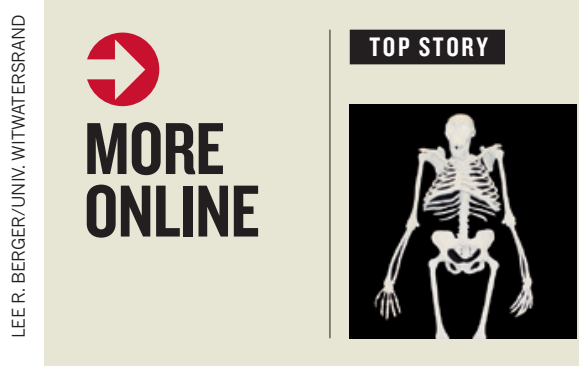

Australopithecus sediba proves to be hodgepodge of ape and human features go.nature.com/ wdasuq

\section{MORE NEWS}

- Egyptian mummies' DNA preserved despite hot climate go.nature.com/bkexht - Supernova left iron-isotope signature in ancient bacteria go.nature. com/3bsqjc

- Lab-grown kidneys transplanted into rats go.nature.com/n3ubgp

\section{VIDEO}

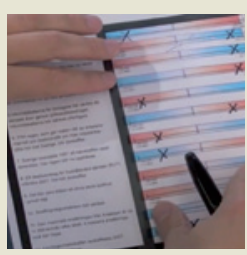

'Choice blindness' trick transforms conservatives into liberals go.nature.com/ vr63qf 